\title{
Urbanity, the Flâneur, and the Visual Qualities of Urban Design: A Walk in Lisbon, Portugal
}

\author{
Vicente del Rio \\ PhD; Professor; CRP Department, Cal Poly.
}

The concept of urbanity and the literary figure of the flâneur are a platform for del Rio's exploration of the visual qualities of urban design in Lisbon's historic core. Drawings are are used throughout this study since they are analyses in themselves and capture the essence of places more than a photo can do. All drawings in this article are by the author.

"Landscape - that's what the city is transformed into for the flâneur. Or, more precisely: for the flaneur, the city is composed by dialectic poles. It opens up for him as a landscape, and closes around him as a room"

(Benjamin, 2007: 462)

am fascinated with Lisbon, Portugal. I feel privileged to have visited the city frequently over the past decade as visiting faculty at the Universidade Lusófona, as director of Cal Poly's summer urban design program there in 2011, and as a researcher during a sabbatical leave (Spring 2013) when the study discussed here got started. I never get tired from exploring Lisbon's cityscape, its geography, urban design and architecture; a city with a deep sense of history and an attractive social and cultural life. I particularly love Lisbon's historic core where all of these qualities comes together in a lively and engaging environment where you can walk tirelessly for hours. This core is approximately 1.5 square miles, includes seven districts (Baixa Pombalina, Avenida, Alfama, Mouraria, Bairro Alto, and Principe Real) and, despite Lisbon's famous hilly topography, is very walkable and well served by public transit.

As an urban designer and studio instructor I love experiencing the historic core's urbanity as a flâneur, discovering and rediscovering Lisbon's urban design visual qualities and learning from it. In this process I have been using photography intensely but also sketching as a means to enjoy and analyze places, representing them and learning from the process. Architectural education continue to stress the importance of sketching places and keeping a sketch-diary but not planning programs, in the US most long detached from physical planning and design. However, with the recent strong resurgence of urban design as a fundamental part of the planning profes-

Note: This article was developed based on the author' poster presentation at the 2015 Conference of the Association of Collegiate Schools of Planning - ACSP, in Houston. sion, we need to return to graphic thinking and to use drawing not only to represent a place but also as a means to study, decompose it, and investigate its fundamental components. This is even more important today when the accessibility and ease of use of digital tools fascinate urban design students so much that perfect models and photorealism become ends in themselves and obfuscate the essence of what is being represented, de-personalizing it. Differently from a perfect digital rendering of an imagined reality (the project), a good sketch is a fusion between the means of representation and the personality of the designer (Richards, 2013). The ease and speed of sketching also facilitates conceptual development, helping the connection between mind and projected futures in a typical graphic thinking process (Laseau, 2001). Thus drawing as a means of representation and analysis feeds drawing as a process.

Not unusually I have simply wondered in the streets of Lisbon with a curious mind and eye, a camera and a sketchbook, without a specific purpose in mind but discovering new streets and places, or new ways and vistas into places I already knew. Like Walter Benjamin's flâneur, I am always fully engaged with what I was seeing and feeling, trying to assimilate as much as I can. In this process, the city history, culture and urbanity with its various physical and spatial components are revealed incrementally, as are its visual qualities: sometimes from afar, predictably, other times surprising me with sudden revelations, but always making my walk a pleasure, and turning the city into an endless learning environment.

\section{On Urbanity and the Flâneur}

Urbanity is a rich, powerful but difficult concept to define. Dictionaries describe urbanity as being about urban life, and link the concept to having good manners and knowing how to behave in social situations or, in other words, to being urbane. The search for urbanity has been constant in the planning and urban design fields. Urbanity is about the presence of differences and the experience of otherness in a city (Baudelaire apud Sennet, 1990: 123) and about being immersed in the public 
sphere while breaking away from the tyranny of individuality (Sennett, 1974). Urbanity is about recognizing different cultural, political, and social points of views in the city. Urbanity is in the vitality and diversity of a city and its spaces (Jacobs, 1961) or, simply put, it is about the human dimension of a city (Gehl, 2010). Of the 253 patterns identified by Christopher Alexander to create a cohesive design language towards more human environments, 64 are directly related to urbanity and the quality of the street environment (Alexander et al 1977). Phenomenologists point out that urbanity is about the existential dimension of place (Norberg-Schulz, 1979), the physical patterns allow for a myriad of small acts that make a place timeless (Alexander, 1979), and the quality in a city that makes you feel at home in public space (Aguiar, 2012).

Even if we cannot define urbanity precisely in words and recognize it more as a feeling, reaching for urbanity is our profession's most noble goal in urban design --understood here as the city's physical and sensual manifestation. We are only able to fully enjoy urbanity and a city's urban design qualities through our daily experiences and explorations and, most certainly, walking.

Walking without a specific purpose, just to enjoy the walk and what is revealed along it is a fundamental way to experience urbanity. This takes us to the concept of the flâneur -French for a stroller or urban observer- which takes us back to $19^{\text {th }}$ century Paris, a time and place when science, culture and urban life where undergoing profound changes. At the time, French culture was western society's paradigm of advanced civilization, and Paris was regarded as the model city. On one hand, under Mayor Haussmann and Napoleon III, Paris was going through intense physical transformations and a "modernization" process. The monumental Paris was created with entire districts giving way to new developments, the urban fabric being cut by new boulevards and punctuated by new squares and monuments, and strict architectural guidelines being imposed in the city core.

On the other hand, Parisians and particularly the growing bourgeoisie, were experiencing an intense public and cosmopolitan life with a strong cultural scene animated by sidewalk cafes, theatres, museums, and arts in general. An extraordinary group of artists (such as Manet, Gaugin, Monet, van Gogh, Toulouse-Lautrec, Rodin, and Matisse), writers and poets (such as Hugo, Dumas, Verne, Zola, Valery, Balzac, Mallarmé, and Baudelaire) helped generate a rich and creative environment throughout the city. Being part of this urban scene and becoming a public figure became an important middle-class value. Water Benjamin (2007) called Paris "the capital of the $19^{\text {th }}$ Century" and several theorists identify this period and the processes taking place there as the birth of modernity. ${ }^{1}$ David Harvey calls Paris the "capital of modernity" (Harvey, 2003).

During this period, French poet and philosopher Charles Baudelaire created the literary figure of the flâneur as a man who takes pleasure in strolling and exploring the streets of Paris, in observ- ing life and its characters. The flâneur represents a life-style that only becomes possible in modern Paris and in the type of society it represents. Later, in his critical writings about the birth of modernism and the capitalist city, Walter Benjamin explored the concept of the flâneur as an urban observer and the emblematic explorer of the modern urban experience but, more importantly, he adopted the concept as an analytical tool: the observer-participant. To David Harvey, the flâneur represents the rise of the Parisian middle class and their need to show themselves in a place and to show disposal of time, therefore the importance of shopping arcades, as pictured by Benjamin. Wilson (1995) notes that the flâneur "spends his day simply looking at the urban spectacle" and that he takes visual possession of the city. Although by definition, the flânerie -or the act of being a flâneur- is an urban experience enabled by all five senses, vision prevails. For Benjamin, the flânerie is above all a visual experience that results from walking. Interestingly, the poet Honoré de Balzac described flânerie as "gastronomy of the eye".

\section{The Flâneur and Visual Qualities in Urban Design}

For the flâneur urbanity is the spectacle and his perception of the city is intrinsically linked to walking and movement, much as in a cinematic experience of space. Urban design theory has always looked for inspiration from these notions considering vision as the main source of environmental images and knowledge. For instance, Camillo Sitte (Collins \& Collins, 1965) and Gordon Cullen (1961) in their critiques of modernism, argued that the visual stimulation caused by unpredictable, complex, and surprising urban morphologies is more engaging, aesthetically pleasing, and essential for urbanity. Jane Jacobs (1961) defended the street as the major space for daily social activities and that, as such, it should create sufficient visual stimulae. Post-Modernism and, more recently, New Urbanism try to recreate the pedestrian's visual and social street experiences as a fundamental factor in urbanity or, as many prefer, as place making (Dutton, 2000). Jan Gehl (1987, 2010) in his tireless research and international work towards more humane cities has always noted the importance of visual perception for place experience.

From the perspective of environmental psychology, and particularly along the gestalt theory, the spatial composition and aesthetics of the street and urban spaces are fundamental for visual perception, imageability and legibility, and affect our decisions and behavior (Lynch, 1960; Smith, 1974; Kopec, 2006). Facade and street edge discontinuities, changing perspectives, variety and contrasts, focal points, enclosures, and perception of figure-ground are among the visual stimulae that captivate our eyes and interest. Research repeatedly shows the close

\footnotetext{
1 Walter Benjamin was a German philosopher and social critic who lived in Paris and committed suicide during the Nazi invasion of 1940. His famous book Passages or Arcades is a posthumously collection of his writings on the life of 19th Century Paris, with particular emphasis on the impacts of capitalism on urban life and on streets and shopping arcades as engaging environments for the flâneur.
} 
relationship between the perception of the environment and human mental and physical health. Recent studies in public health suggest a direct causal relation between the quality of street environments and obesity: interesting, captivating, and safe streets and public spaces tend to encourage people to walk more (Ewing et al, 2006). Through a literature review of classic works, Ewing and Clemente (2013) identified 51 perceptual qualities of urban design and selected those that most directly stimulate walking: imageability, enclosure, human scale, transparency, complexity, coherence, legibility, and linkage. Writing from a neuroscience perspective, Ferris Jabr (2014) seems to be referring to the flâneur when noting how walking stimulates the brain, lets it free to wander, and helps us think by "overlaying the world before us with a parade of images from the mind's theatre", a mental state linked to insights and innovative ideas.

For the scope of my studies, the concept of flâneur is extremely useful since it represents he/she who is directly and indirectly, intentionally and unintentionally affected by urbanity and the design of cities through perceptions and experiences as an observer-participant. By embodying the concept of the flâneur as an observant-participant I wondered in Lisbon's historic core, getting lost, observing, being attracted, and exploring the city and its life, and looking for the urban design qualities that engaged me in my visual exploration, making my flânerie a pleasure and a memorable experience. For my observations I applied concepts from various authors who defend the notion of fundamental visual urban design qualities that engage us and generate meaningful places and good cities.

\section{The Flâneur in Historic Lisbon}

Inspired by Lynch (1981), my discussion on the engaging urban design visual qualities in Lisbon must start by considering three meta-qualities: imageability, legibility, and human dimension. Without them the flâneur would not exist, or rather, he/she wouldn't be moved by the city, would not experience any sense of place, and certainly would not want to walk its streets. The manifestation (presence, composition, intensity, and interplay) of these meta-qualities have a direct impact on urbanity and dictates the flânerie and the urban experience proper. Lisbon is imageable because of its strong identity and uniqueness, and it is legible because it is easy for to navigate it and to find our way around it. The human dimension is embodied in the warmth of its people and its public life, in the pace of Portuguese life, and in the scale of the city and most of its architecture. These meta-qualities result from the unique interplay between geography, history, culture, urban form, architecture, and people.

Next, there are specific urban design visual qualities that engaged me as a flâneur and made my flânerie in Lisbon's historic core a pleasure, a constant invitation to walk and see just a bit more. In the following lines, I will try to illustrate this experience and the qualities through brief discussions and drawings.

\section{Complexity and Surprise}

The flânerie is fed by the visual composition of places and, particularly, the space that lay ahead and the options we perceive as the next steps, in our desire to continue walking and experiencing the city. Discontinuities in the morphology, unexpected angles and dead-ends, multiple decision-points, narrow passages, sudden revelations, contrasts, succeeding views, stimulating tensions. Cullen (1961) notes that these qualities, the emotions and the drama they reveal depend on the dynamics between the place one's are at and the emerging views that are revealed by walking, a notion he calls serial vision. For Smith (1974: 236) "a creative townscape is that which stimulates the mind... generating images and motivating exploration". Rapoport (1969) defines environmental complexity when the mind is attracted by the multiplicity of information and options for behavior. A flâneur finds plenty of that in the streets of historic Lisbon, particularly in the medieval morphology of the Alfama and the hilly Bairro Alto.

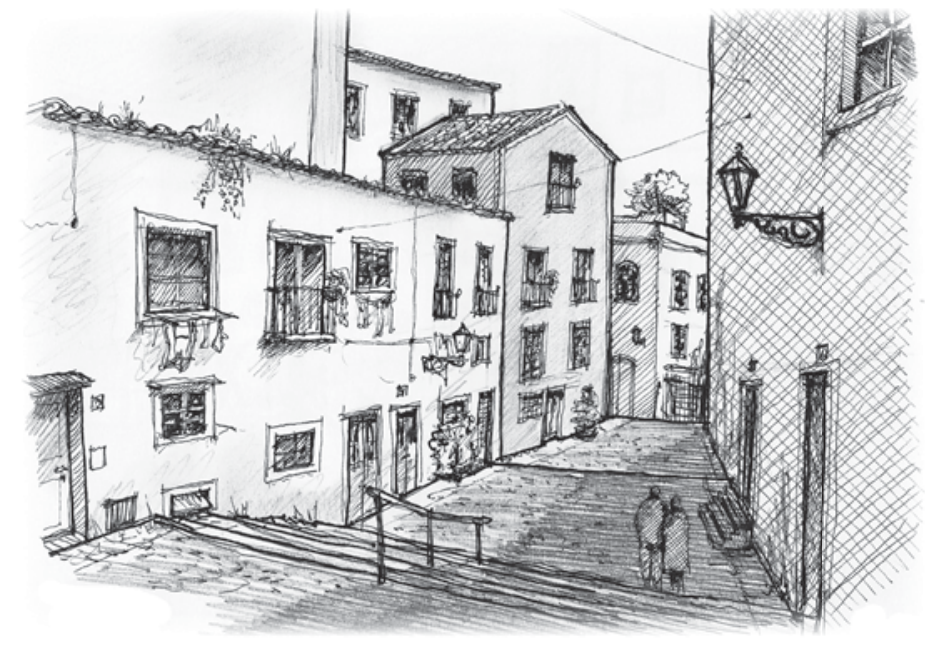

Complexity and surprise in urban design keeps the mind curious and the walk more rewarding. An alley in Alfama (top) and a building arching over Rua dos Academicos invites the flâneur to explore even further.

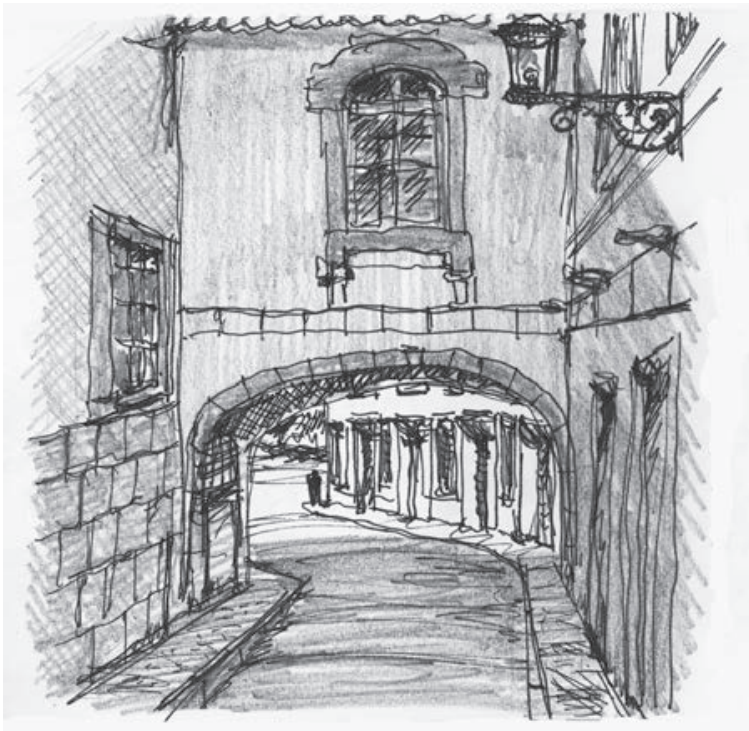




\section{Vitality and Robustness}

Social and human activities are crucial for the perception of vitality and for sense of place (Canter, 1977; Gehl 1987, 2010; Whyte, 1980; Lynch 1981). The flâneur is engaged by activities that liven up and give meaning to the streets and spaces he walks through. A place or street is robust when it offers a variety of land uses, density, activities, and behavioral choices that sustain its vitality in the long run, attracting different people at different times. Streets, squares and plazas in historic Lisbon are filled with life from the mixture of residences and a myriad of small shops, restaurants, cafes, and bars with sidewalks seating, plus small kiosks selling newspapers and magazines, snacks, coffee or drinks. One of the drawings depicts Praça Camões, a popular hangout place day and night and a favorite for all sorts of social manifestations, whose simple design supports behavior and is adapted to topography and an underground parking. The other drawing shows a historic kiosk in Praça Principe Real specializing in coffee, while another at the opposite corner opens exclusively at rush time for beer and cigars and attracts a huge young crowd!

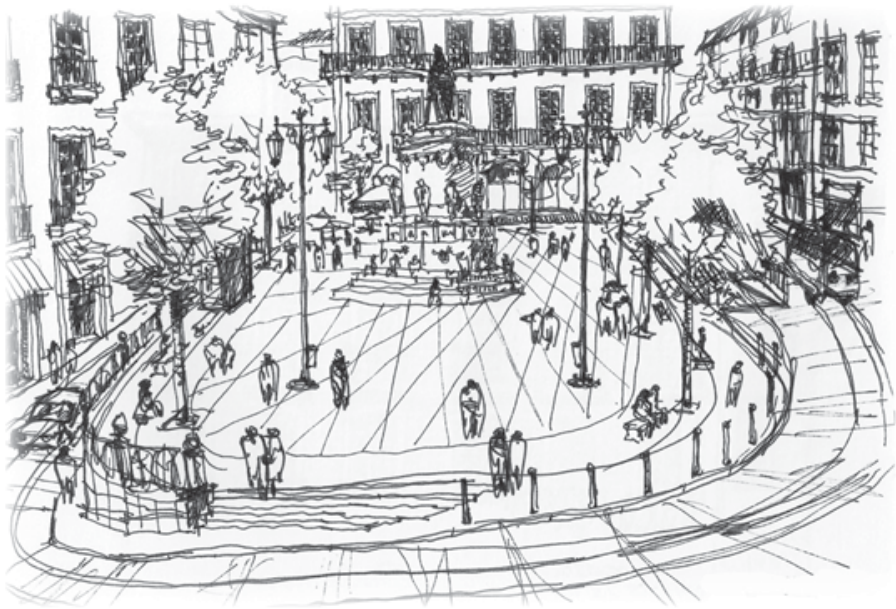

Robust spaces like Praca Camoes in Bairro Alto (above) become social nodes and incorporate changes over time. Kiosks seeling food, coffee, beverages and beer (below) help inject vitality in the public realm.

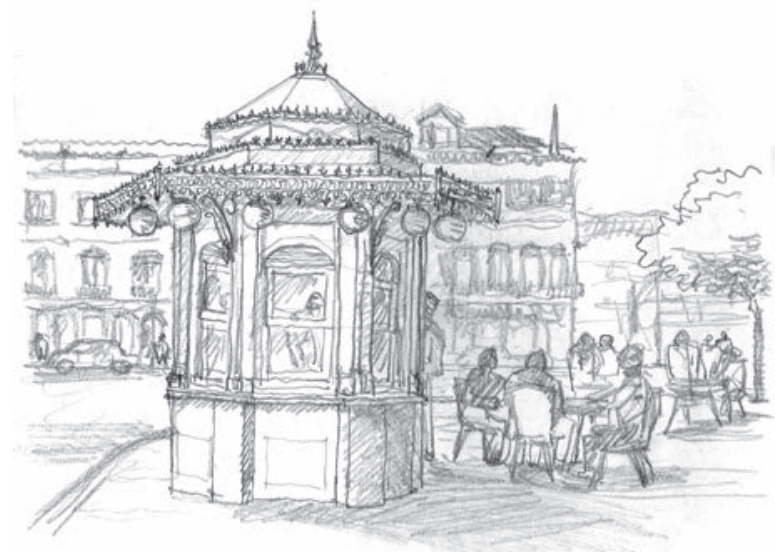

\section{Enclosure and Linkages}

Urban design studies agree that enclosure through well defined edges and facilitating a sense of position are fundamental place qualities due to their deep psychological meanings, making us feel confortable and in control of our whereabouts. The correct proportions between a space and its edges (surrounding buildings or perceived defining places) make us feel comfortable, protected, and in control of our surroundings. A well-defined space with visible entrances and clear edges is a defensible space. Defining edges lead our walk to spaces beyond through linkages in the urban tissue, contributing to the feeling of accessibility and continuity. The perception of a way out of a place and being able to move from point $a$ to $b$ is as important as the feeling of enclosure and defensible space: they are complementary. The flâneur finds plenty of enclosed spaces and linkages in historic Lisbon, with the most compelling examples in the old moorish and medieval hilly district of Alfama. Even the regular baroque design of squares at the Baixa Pombalina, though of a more monumental proportions, provide an excellent sense of enclosure and clear linkages to the surrounding city.

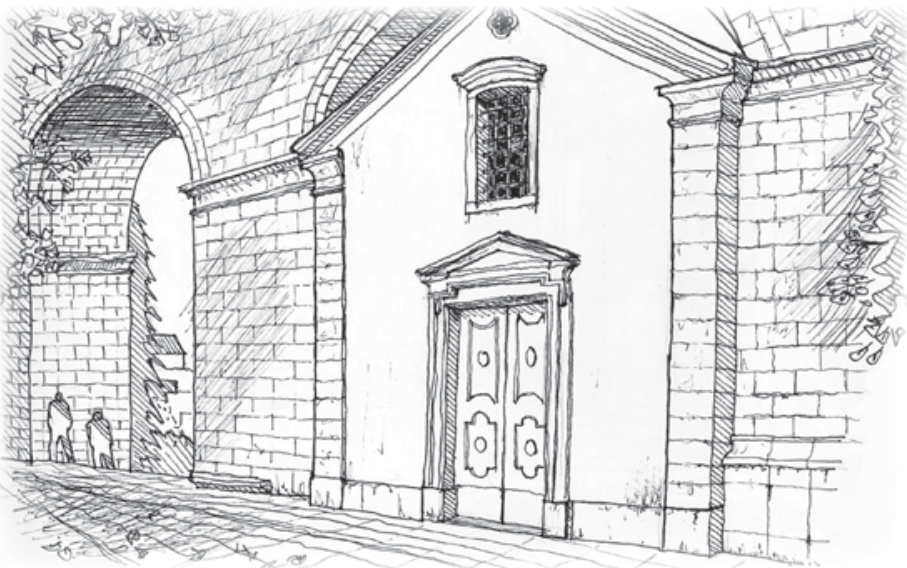

Parque das Amoreiras is a well enclosed small park with one side defined by a XVII Century acqueduct where a small church was built into one of the arches. Below, an elaborate street design with double ramps access Parque Principe Real.

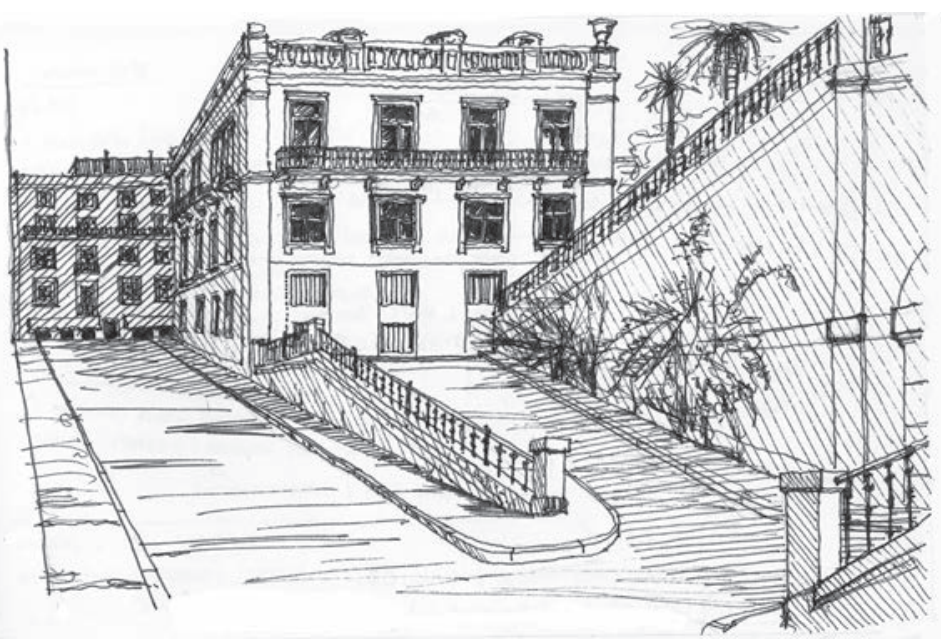




\section{Transparency and Vistas}

Transparency is the quality that allows us to see or perceive what lies beyond an edge or, in other words, being able to be in a place whilst seeing out of it into another place and its activities (Cullen, 1962; Ewing et al, 2006). When the edge opens up towards a far horizon or a clear focal point we are dealing with vistas -some of them only glimpses- that capture the eye and attract the flâneur. These concepts, together with enclosure and linkages, are grounded in the human topological need of locating one's body while at the same time being confortable enough to participate in a place beyond, always feeling safe due to the visual control of the spaces and the perceived link between both places.

The streets of Lisbon are lined up by buildings whose traditional typology is punctuated by windows and doors, generating a dynamic public-private relationship. The adaptation of Lisbon's morphology to topography and to historical processes with its architectures plenty of windows and doors, lend the perfect conditions for a flâneur to be constantly attracted by vistas and

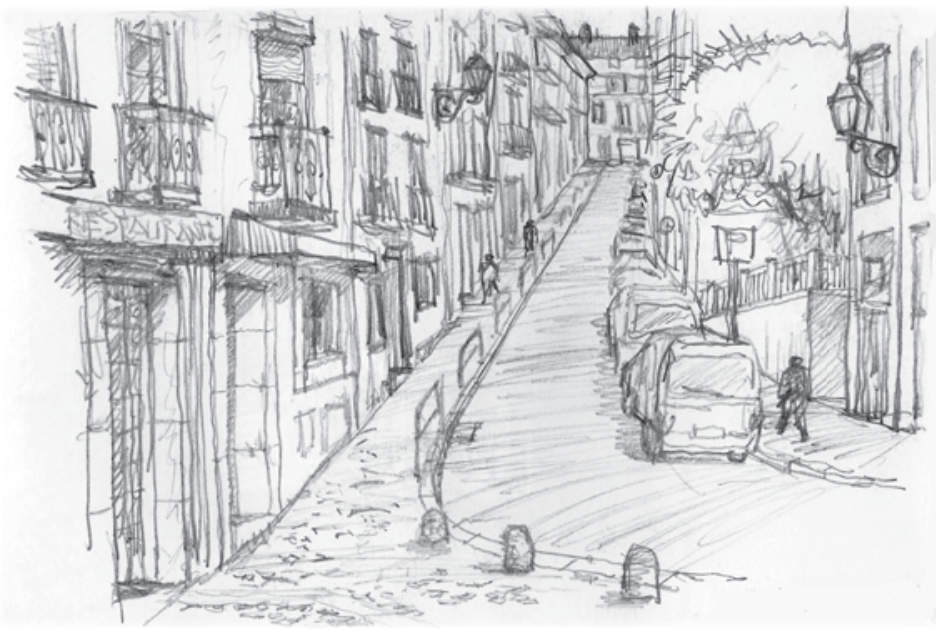

The transparency of historic buildings help animate Lisbon's streets, and the interplay between city form and topography constantly reveal surprising vistas such as from Miradouro da Graça to Castelo de São Jorge. transparencies. Lisbon is a city of miradouros, or places to enjoy dominating views towards the valley, the other hills, and the river. Several miradouros are next to important historical buildings and complemented by landscaping, cafes and seating, such as the one depicted in the drawing.

\section{Legibility and Coherence}

The human brain and the flâneur need a legible city with a recognizable overall form, a clear relationship between districts and neighborhoods, and a set of coherent spaces and architectures for a mental map. Legibility refers to the ease that a city or a place may be navigable and understood as a whole, and coherence makes for a certain degree of visual order (Lynch, 1960, 1981; Ewing \& Clemente, 2013). These qualities are counterpoints for the flâneur's need for surprises and complexity but are fundamental to provide him/her with an understanding of the whole and moments of reassurance. Usually, streets and spaces of high legibility are robust nodes full of vitality, are punctuated by monuments, and become highly meaningful places, detaching themselves in the flâneur's

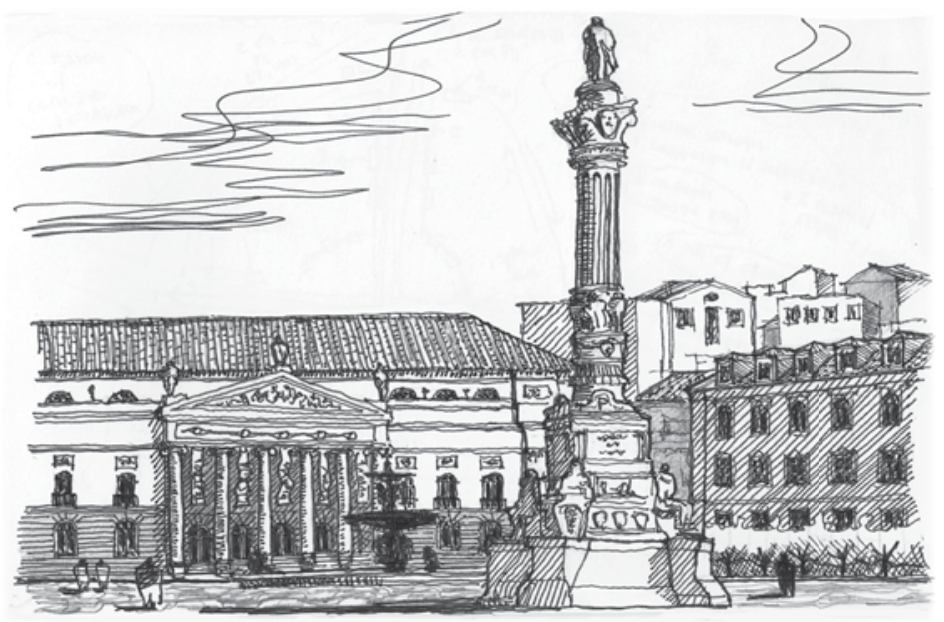

In Lisbon, the clear relationship between city tissue, hills, and river generates a strong mental map. This is helped by clear paths (avenues) and strong nodes, such as Rossio (above) leading to Praça do Comercio and the river.
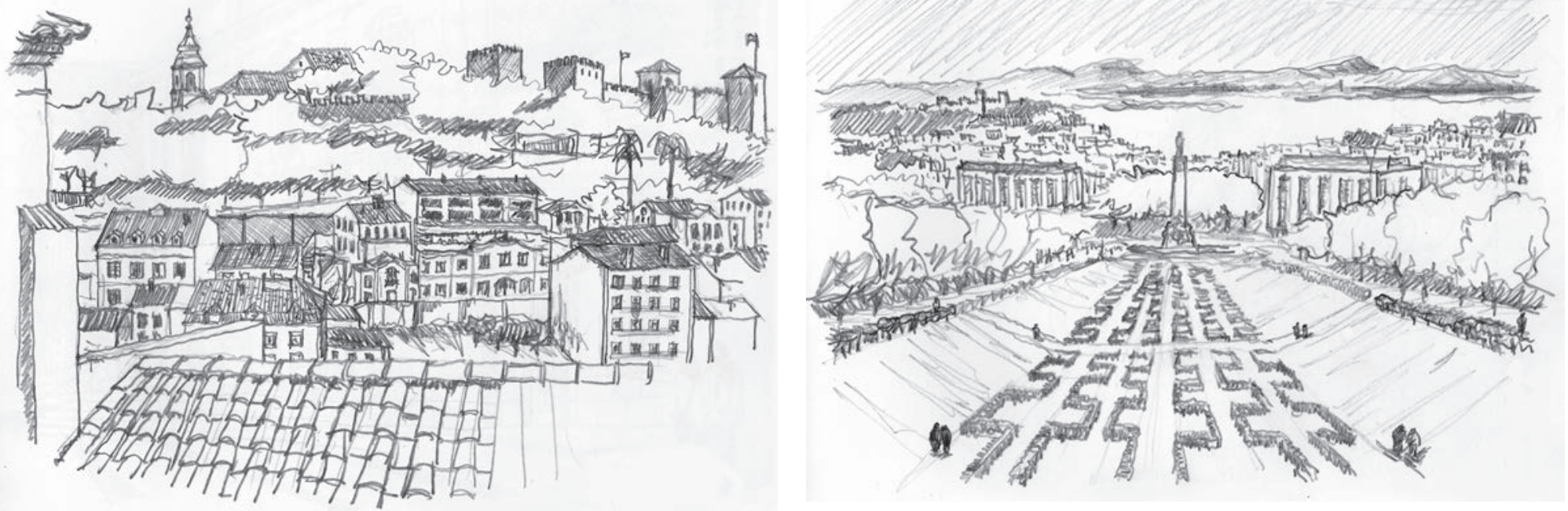
mental map. The legibility and coherence in Lisbon's historic core are facilitated by the geography, hills and gentle sloping valley towards the Tagus river. A major monumental axis connects the top of a hill to the valley and the river through the regular grid of enlightened baroque Baixa Pombalina, the area rebuilt after 1755 's big earthquake, adding to the dramatic and monumental parcours towards and the monumental archway to Praça do Comercio and the riverfront.

\section{Architectural Richness}

Architecture is said to be the only inescapable art form as one cannot avoid experiencing it on a daily basis. In experiencing the city, architecture is always present in the buildings (style, shape, ornamentation, colors, etc), streetscape (paving, street furniture, planting, etc), and punctuating elements (statues, fountains, etc). Lisbon's historic architecture is of an incredible richness of ornamentation, and the city's sidewalks and squares are famous for their beautiful handset cobblestone mosaics. These elements add extreme value to the visual perception of the city. They add to surprise and complexity by keeping the eye busier in appreciating and making sense
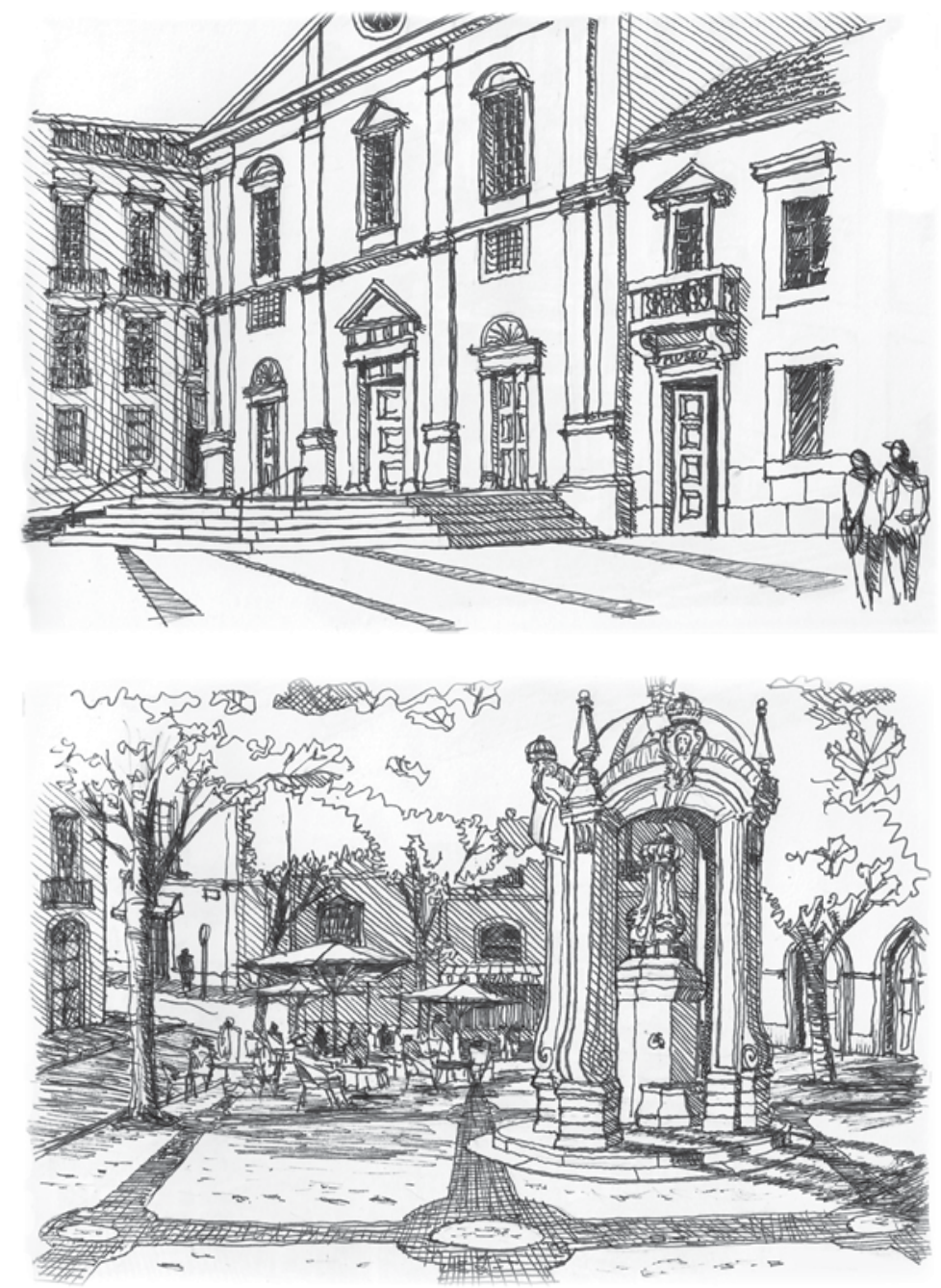

of details. They add to the legibility and coherence as they add character and identity to a place or street, an area or the whole city. Architectural richness adds a fine grain of aesthetic enjoyment to the experience of the flâneur, keeping him constantly engaged in his walk.

\section{Personalization and Community Values}

A responsive design allows for personalization by residents and users find ways to imprint their marks in buildings, space, and time, making the built environment their own and an expression of their selves. Spaces that become places due to a series of individual and collective imprints, normally resulting from participatory processes between neighbors, are living expressions of community values. Lisbon's historic core is a great example with dead-end streets and alleys taken over and decorated by neighbors, the colorful clothes drying lines hanging off windows, and public and semi-public spaces richly decorated and adapted to traditional and religious events such as the lively festas. These practices allow the flâneur's imagination to connect people to place and embark on a myriad of imagined personal stories.

\section{A Conclusion?}

It is hard to end this essay due to the strong power of attraction that Lisbon's landscapes, morphologies, spaces, and architectures exert on the urbanist-flâneur and the lessons we can learn from them. Relationships between built, un-built and topography; imageability and legibility; continuities and transparencies; appropriateness and contextuality of architectural typologies; scale, textures and materials; coherence, transparency and visual order; enclosure and linkages; density of life and complementarity of land uses.
Lisbon's architectural richness is a visual feast to the flâneur: the levels of history revealed by the styles (such as in the baroque São Roque church and old hospital), the architectural details (such the art-nouveau door below), and the monuments and sidewalk coble stone designs (such as in Largo do Carmo with its unique XVIII century fountain).

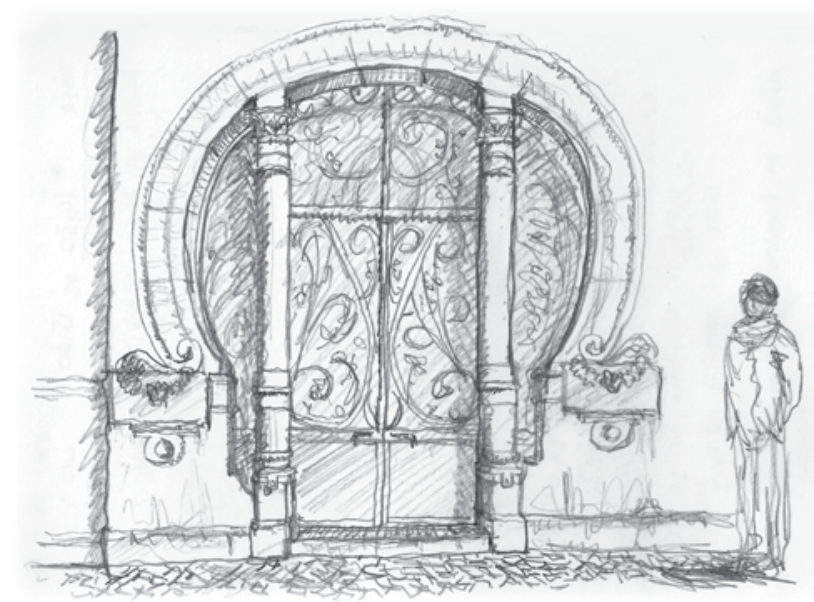


Wandering around the historic center of this magnificent city with eyes and brain wide open teach us how urban compositions influence our perception of space, our expectations and behavior, making of our flânerie a pleasurable and memorable a experience in a process of discoveries and continuous awareness of Lisbon's urbanity and urban design qualities. Sketching some of these moments allowed me to take time to look carefully, analyze and capture the essence of the place; a much more intense and relational process than simply taking a photo. And perhaps the most important conclusion is that the planner and urban designer should use the concept and method of the flâneur, the observer-participant, and imagine him/herself experiencing his/her plan or design, enjoying the imagined urbanity and the projected visual experiences. If he/ she finds that these flâneries are memorable experiencse, then perhaps, successful new urban places will come out of the drawing board (or computer...).

\section{References}

Aguiar, Douglas. 2012. Urbanidade e Qualidade da Cidade. in D. Aguiar \& V. Netto (eds) Urbanidades. Rio de Janeiro: Letra \& Imagen.

Alexander, Christopher et al. 1977. A Pattern Language. Oxford: Oxford University Press.

Alexander, Christopher. 1979. The Timeless Way of Building. Oxford: Oxford University Press.

Benjamin, Walter. 2007. Passagens. (Brazilian edition of the German original Das Passages-Werk). Belo Horizonte: Editora da Universidade Federal de Minas Gerais.

Canter, David. 1977. The Psychology of Place. London: Architectural Press.

Collins, George \& Collins, Christiane. 1965. Camillo Sitte and the Birth of Modern Planning. London: Random House.

Cullen, Gordon. 1961. Townscape. London: Architectural Press.

Dutton, John. 2000. New American Urbanism - Re-forming the Suburban Metropolis. Milão: Skyra.

Ewing, Reid and Clemente, Otto. 2013. Measuring Urban Design: Metrics for Livable Places. Washington, DC: Island Press.

Ewing, Reid et al. 2006. Identifying and Measuring Urban Design Qualities Related to Walkability. In Journal of Physical Activity and Health 3, suppl. 1.

Gehl, Jan. 2010. Cities for People. Washington, DC: Island Press. 1987. Life Between Buildings. New York: Van Nostrand Reinhold.
Jabr, Ferris. 2014. Why Walking Helps Us Think. In The New Yorker; at <http://www.newyorker.com/tech/elements/ walking-helps-us-think?src $=\mathrm{mp}>$ (access on Sept. 3, 2014).

Jacobs, Jane. Death and Life of Great American Cities. Penguin.

Kopec, Dan. 2006. Environmental Psychology for Design. Nova lorque: Fairchild.

Laseau, Paul. 2001. Graphic Thinking for Architects and Designers. Nova lorque: John Wiley.

Lynch, Kevin. 1981. A Theory of Good City Form. Cambridge MA: MIT Press

1960. The Image of the City. Cambridge MA: M.I.T. Press.

Norberg-Schulz, Christian. 1979. Genius Loci: Towards a Phenomenology of Architecture. London: Academy Editions.

Rapoport, Amos. 1977. Human Aspects of Urban Form. Oxford: Pergamon Press.

Richards, James. 2013. Freehand Drawing and Discovery. Nova Jersei: John Wiley

Sennet, Richard. 1990. The Conscience of the Eye - The Design and Social Life of Cities. New York: W.W. Norton. 1974. The Fall of Public Man. Oxford: Oxford University Press.

Smith, Peter. 1974. The Dynamics of Urbanism. London: Hutchinson Educational.

Whyte, William. 1980. The Social Life of Small Public Spaces. Washington, DC: The Conservation Foundation.

Wilson, Elizabeth. 1995. The Invisible Flâneur. In S. Watson \& K. Gibson (eds) Postmodern Cities and Spaces. Oxford: Blackwell. 